\title{
Transformational and Devious Leadership and How it Predicts Stress and Workplace Wellbeing
}

\author{
Per Eisele
}

Department of Civil and Industrial Engineering, Uppsala University, Sweden

\begin{tabular}{|c|c|}
\hline & ABSTRACT \\
\hline $\begin{array}{l}\text { Keywords: } \\
\text { Constructive leadership, } \\
\text { Transformational leadership, } \\
\text { Destructive leadership, } \\
\text { Abusive supervision, Stress, } \\
\text { Workplace wellbeing } \\
\text { Received }\end{array}$ & \multirow[t]{7}{*}{$\begin{array}{l}\text { The aim of the present study was to examine the predictive power of constructive and } \\
\text { destructive leadership on employee stress and workplace wellbeing. The measurements were } \\
\text { the global transformational leadership scale, a devious leadership scale, the perceived stress } \\
\text { scale and a workplace wellbeing scale. A sample of } 423 \text { employees from both public a private } \\
\text { sector filled out a questionnaire at the time of their choice. Results indicate that destructive } \\
\text { leadership (but not constructive leadership) predicts both stress and workplace wellbeing. } \\
\text { Furthermore, employees from the public sector reported significantly higher level of } \\
\text { destructive leadership behavior compared to employees from the private sector. }\end{array}$} \\
\hline 13 September 2020 & \\
\hline Received in revised form & \\
\hline 02 October 2020 & \\
\hline Accepted & \\
\hline 04 October 2020 & \\
\hline $\begin{array}{l}\text { *Correspondence: } \\
\text { per.eisele@gmail.com }\end{array}$ & \\
\hline
\end{tabular}

Recently there has been an increased number of papers on the relation between leadership and employee wellbeing. For a long time, it was a neglected area (Donaldson-Feilder, Munir, \& Lewis, 2013). Leadership can have impact on employee wellbeing in many different ways including either diminishing or enhancing positive and negative effect. Passive destructive leadership can cause stress while active constructive leadership is associated with being supportive and thereby decreasing stress. Research on constructive leadership is still much more frequent compared to studies investigating different forms of destructive leadership. However, studies investigating destructive leadership or abusive supervision are increasing (Schyns \& Schilling, 2013). 


\section{Destructive Leadership}

Yukl (2006) defined destructive leadership as "a process in which over a longer period of time the activities, experiences and/or relationships of an individual or the members of a group are repeatedly influenced by their supervisor in a way that is perceived as hostile and/or obstructive". There are many different forms of destructive leadership and much research is called for to understand better how it is related to negative outcomes such as perception of leader, turnover intention, performance and well-being.

Effects of destructive leadership on followers have been found to be severe in several studies (Hoobler \& Brass, 2006). Although, some scholars question the concept of destructive leadership with the argument that to manipulate followers is not leading (Yukl, 2006). But when a formal leader abuse or manipulate followers' employees perceive such behavior as destructive leadership. In a meta-analysis by Schyns and Schilling (2013) on the relationship between destructive leadership and outcome variables indicate the expected negative correlations with positive followers' outcomes and behaviors (e.g., attitudes towards the leader, well-being, and individual performance) and positive correlations with negative outcomes (e.g., turnover intention, resistance towards the leader, counterproductive work behavior). The highest correlation found was between destructive leadership and attitudes towards the leader.

The concept of destructive leadership can be seen as an umbrella term incorporating many different forms. The concept of devious leadership has been developed based on the idea that those aspects which influence followers and that can be perceived by employees are most important. Other researchers have also acknowledged the idea that perceivable actual behavior is the most important aspect of destructive leadership. For example, abusive supervision (Tepper, Moss, Lockhart, \& Carr, 2007), supervisory abuse (Bamberger \& Bacharach, 2006) and aversive leadership (Bligh, Kohles, Pearce, Justin, \& Stovall, 2007).

There are at least two problems with limiting measures to abusive leadership. First, only followers received such abuse knows about its existence at the organization. It is in this sense similar to workplace bullying (Salin et al., 2019). Secondly, some abusive behavior might be deliberate actions but some happens unintentionally. In a previous study on effect of leadership coaching on employee wellbeing, one leader reported apologizing to an employee for her behavior (Eisele, 2020b).

Devious leadership is on type of destructive leadership, incorporating some part of abusive supervision as well as other type of destructive leadership such as manipulating followers or being unfair.

\section{Constructive Leadership}

The link between constructive leadership and employee wellbeing is well established. For example, Farahnak, Ehrhart, Torres and Aarons (2020) found support for positive relationships between transformational leadership and employee's attitudes toward change. However, Skogstad, Aasland, Nielsen, Hetland, Matthiesen and Einarsen (2015) investigated the relative influence of constructive, laissez-faire, and tyrannical leadership behaviors on followers' job satisfaction. Destructive forms of leadership were the only significant predictor.

The most common type of constructive leadership is transformational leadership where a leader works with teams to identify needed change, creating a vision to guide the change through inspiration, and executing the change in tandem with committed members of a group (Bass, 1990). 
In the present study a short form of transformational leadership (Carless, Wearing, \& Mann, 2000) was used as the measurement of constructive leadership. In short, devious leadership is on form of destructive leadership just like transformational leadership is one form of constructive leadership.

\section{Stress}

Certain leadership styles are associated with increases in employee performance (Veliu, Manxhari, Demiri, \& Jahaj, 2017), but since this will involve working harder and spending more time negative outcomes for employee health are to be expected (Nielsen \& Taris, 2019). A study on passive leadership as a potential antecedent of workplace stressors and its negative effect on employee burnout and physical symptoms showed that passive leadership was positively related to employee burnout and physical symptoms (Che, Zhou, Kessler, \& Spector, 2017).

In the present study perceived stress was used as the dependent variable. The Perceived Stress scale has in several studies displayed adequate psychometric properties (Ribeiro Santiago, Nielsen, Smithers, Roberts, \& Jamieson, 2020).

\section{Workplace Wellbeing}

Employee well-being should be strategically relevant to organizations. The concept of wellbeing is used differently, sometimes broadly involving health and stress and sometimes specific and then often limited to positive and/or negative effect. One large instrument of employee well-being developed by Pradhan and Hati, (2019) is formed by four discreet factors: social well-being, psychological well-being, subjective well-being and workplace well-being. The present study made use of workplace wellbeing instrument similar to the mental health continuum developed by Corey Keyes (Keyes, 2002; Reinhardt, Horváth, Morgan, \& Kökönyei, 2020) that is built upon emotional wellbeing, psychological wellbeing and social wellbeing.

One of the bases of the present study was to gather data that could increase understanding on how to make better use of leadership as an intervention tool for healthier workplaces. improving leadership behavior (Eisele, 2020a; Kelloway, \& Barling, 2010) has a great potential and is a more straightforward approach than for example job redesign (Holman, Axtell, Sprigg, Totterdell, \& Wall, 2010) or increased organizational justice (Demir, 2011).

The present study was designed to examine whether constructive and destructive leadership predicts stress and workplace wellbeing of employees.

\section{Method}

\section{Participants}

A sample of 423 employees from both public and private sector filled out the questionnaire at the time of their choice, totaling 214 women with a mean age of 38.22 and 209 men with a mean age of 39.81 .

\section{Material}

\section{Transformational Leadership}

The global transformational leadership scale (GTL) (Carless, Wearing, \& Mann, 2000) consists of seven items. Response categories are loaded on a five-degree scale varying from $1=$ To a very large extent to $5=$ To a very small extent. Example item: "My closest supervisor is clear about 
his/her values and practices he/she preaches". Both internal consistency and nomological validity have been found to be adequate (Van Beveren, Dimas, Lourenço, \& Rebelo, 2017).

\section{Devious Leadership}

Devious leadership scale (DLS) consists of 10 items. Response categories are loaded on a fivedegree scale varying from $1=$ To a very large extent to $5=$ To a very small extent. Example item: "My closest supervisor terrorizes and threaten followers". The DLS has recently been used in a longitudinal study with satisfactory internal consistency (Eisele, 2020b).

\section{Stress}

The PSS-10 (Liu, Zhao, Li, Dai, Wang, \& Wang, 2020) measures components of stress by assessing how uncontrollable, overloaded, and unpredictable individuals find their lives. The PSS-10 asks about thoughts and feelings over the last month using a response scale from 0 (never) to 4 (very often). Example item: "In the last month, how often have you felt nervous and 'stressed'?" The PSS-10 has been found to be a valid and reliable self-report measure of perceived stress (Makhubela, 2020).

\section{Workplace Wellbeing}

The Workplace Wellbeing Scale (WWS) consists of 11 items which load on emotional wellbeing, psychological wellbeing and social wellbeing and makes uses of a six-degree scale that varies from never to all days within a period of one month. Example item: "In the last month, how often have you felt energized at work". The WWS has recently been used in several studies with satisfactory internal consistency (Eisele, 2020a;2020b).

\section{Procedure}

Several studies prior to the present paper have been based on data from one large civil service company (Eisele, 2020b). To be able to compare data from other type of companies, including private sector a different sampling approach was used for the present study. Via different forms of social media, the questionnaire was presented and made able to fill out via a link. Data was collected in 2019 until the covid-19 crisis changed the work conditions dramatically. Consent was given both by clicking the link and by the first page of the questionnaire. All participants had the possibility to remain completely anonymous, name and email being voluntary.

\section{Result}

All scales had sufficiently high internal consistency with Cronbach's Alphas for GTL .87, for DLS .82 , for PSS .93, and for WWS .90. The difference between public and private sector was significant for all variables. Mean values indicating more negative scores for participants in public sector compared to private sector, as presented in Table 1. Linear regressions were made to explore the predictive value of constructive and destructive leadership on stress and workplace wellbeing. 
Table 1

Means and Standard Deviations of the Dependent Variables Across Public and Private Sector

\begin{tabular}{|c|c|c|c|c|c|c|c|c|}
\hline & \multicolumn{2}{|c|}{ Transformational leadership } & \multicolumn{2}{|c|}{ Devious leadership } & \multicolumn{2}{|l|}{ Stress } & \multicolumn{2}{|c|}{ Workplace wellbeing } \\
\hline & $M$ & $S D$ & $M$ & $S D$ & $M$ & $S D$ & $M$ & $S D$ \\
\hline Private $n=116$ & 3.56 & .64 & 2.65 & .98 & 3.74 & .49 & 3.65 & .62 \\
\hline Public $n=307$ & 2.15 & .48 & 4.34 & .56 & 4.11 & .42 & 2.32 & .78 \\
\hline$t$ & 21.66 & & 17.45 & & 8.21 & & 15.58 & \\
\hline$d f$ & 167.64 & & 143.76 & & 421 & & 260.82 & \\
\hline$p$ & $<.001$ & & $<.001$ & & $<.001$ & & $<.001$ & \\
\hline
\end{tabular}

Devious leadership predict both perceived stress (Table 2) and self-reported workplace wellbeing (Table 3). Transformational leadership did not predict neither perceived stress nor workplace wellbeing (Table 2 and 3).

Table 2

Predictors of Perceived Stress

Perceived stress

\begin{tabular}{llll}
\hline variable & $\beta$ & $95 \% \mathrm{CI}$ & $3.37]$ \\
\hline constant & $2.75^{* *}$ & {$[2.13$} & $.19]$ \\
Transformational leadership & .08 & {$[-.03$} & $.36]$ \\
Devious leadership & $.27^{* *}$ & {$[.18$} & \\
$R^{2}$ & & & \\
$F$ & .21 & & \\
Note: $\mathrm{N}=422, * * p<.001$ & $55.32^{* *}$ & &
\end{tabular}

Table 3

Predictors of Workplace Wellbeing

\begin{tabular}{llll}
\hline & & & \\
& & & \\
\hline variable & $\beta$ & $95 \% \mathrm{CI}$ & $5.14]$ \\
\hline constant & $4.18^{* *}$ & {$[3.22$} & $3.42]$ \\
Transformational leadership & .17 & {$[-.007$} & $-.32]$ \\
& & & \\
Devious leadership & $-.46^{* *}$ & {$[-.60$} & \\
$R^{2}$ & .45 & & \\
$F$ & $170.65^{* *}$ & &
\end{tabular}

\section{Discussion}

Destructive leadership predicted both stress and workplace wellbeing. Additionally, large differences were found between public and private sector. To conclude, studies based on measurements of only constructive leadership might miss too much of the big picture.

However, several limitations need to be taken into consideration. In the data there is an indication of regression to the mean but this should only lessen the found effects. More important is the sampling issues. It is possible and perhaps even likely that there are public sector companies and private sector companies with different patterns than found in the present study. Also, employees with negative experiences of their leaders might be more motivated to participate in a leadership study. The sample is therefore not representative. On the other hand, a sample from one 
firm is not representative either. The findings need to be replicated in studies on several different companies as well as different cultures.

Destructive forms of leadership seem to be better predictors of job satisfaction than are constructive forms of leadership which are in line with earlier studies (Skogstad et al., 2015). The question then is how can good leadership be promoted? There is a need to develop interventions that are effective in promoting desirable leadership styles (Nielsen \& Taris, (2019). Activity-based leadership coaching (Eisele, 2020b) had stronger and more reliable effect on workplace wellbeing than a general leadership development program (Eisele, 2020a). The main reason for that could be that coaching has a better chance of decreasing destructive behavior of leaders. That is, a leadership development program is more focused on good leadership. The present study highlighted the importance of further addressing destructive leadership in future studies.

\section{References}

Aasland, M. S., Skogstad, A., Notelaers, G., Nielsen, M. B., \& Einarsen, S. (2010). The prevalence of destructive leadership behaviour. British Journal of Management, 21(2), 438-452.

Bamberger, P. A., \& Bacharach, S. B. (2006). Abusive supervision and subordinate problem drinking: Taking resistance, stress and subordinate personality into account. Human Relations, 59(6), 723-752.

Bass, B. M. (1990). From transactional to transformational leadership: Learning to share the vision. Organizational Dynamics, 18(3), 19-31

Bligh, M. C., Kohles, J. C., Pearce, C. L., Justin, J. E., \& Stovall, J. F. (2007). When the romance is over: Follower perspectives of aversive leadership. Applied Psychology, 56(4), 528-557.

Carless, S. A., Wearing, A. J., \& Mann, L. (2000). A short measure of transformational leadership. Journal of Business and Psychology, 14(3), 389-405.

Che, X. X., Zhou, Z. E., Kessler, S. R., \& Spector, P. E. (2017). Stressors beget stressors: The effect of passive leadership on employee health through workload and work-family conflict. Work and Stress, 31(4), 338-354.

Demir, M. (2011). Effects of organizational justice, trust and commitment on employees' deviant behavior. Anatolia, 22(2), 204-221.

Donaldson-Feilder, E., Munir, F., \& Lewis, R. (2013). Leadership and employee wellbeing. The Wiley-Blackwell handbook of the psychology of leadership, change, and organizational development, 155-173. Wiley: West-Sussex, UK.

Eisele, P. (2020a) Effects of a leadership development program on employee's well-being. Journal of Occupational Health Psychology. Manuscript submitted for Publication.

Eisele, P. (2020b) Effects of activity-based leadership coaching on employee's well-being. Journal of Occupational Health Psychology. Manuscript submitted for Publication.

Farahnak, L. R., Ehrhart, M. G., Torres, E. M., \& Aarons, G. A. (2020). The influence of transformational leadership and leader attitudes on subordinate attitudes and implementation success. Journal of Leadership \& Organizational Studies, 27(1), 98-111.

Holman, D. J., Axtell, C. M., Sprigg, C. A., Totterdell, P., \& Wall, T. D. (2010). The mediating role of job characteristics in job redesign interventions: A serendipitous quasi-experiment. Journal of Organizational Behavior, 31(1), 84-105.

Hoobler, J. M., \& Brass, D. J. (2006). Abusive supervision and family undermining as displaced aggression. Journal of Applied Psychology, 91(5), 1125 .

Kelloway, E. K., \& Barling, J. (2010). Leadership development as an intervention in occupational health psychology. Work and Stress, 24(3), $260-279$.

Keyes, C. L. (2002). The mental health continuum: From languishing to flourishing in life. Journal of Health and Social Behavior, $207-222$.

Liu, X., Zhao, Y., Li, J., Dai, J., Wang, X., \& Wang, S. (2020). Factor structure of the 10-item perceived stress scale and measurement invariance across genders among Chinese adolescents. Frontiers in Psychology, 11, 537. https://doi.org/10.3389/fpsyg.2020.00537

Makhubela, M. (2020). Assessing psychological stress in South African university students: Measurement validity of the perceived stress scale (PSS-10) in diverse populations. Current Psychology, 1-8.

Nielsen, K., \& Taris, T. W. (2019). Leading well: Challenges to researching leadership in occupational health psychology-and some ways forward. Work and Stress, 33(2), 107-118.

Pradhan, R. K., \& Hati, L. (2019). The measurement of employee well-being: development and validation of a scale. Global Business Review, 0972150919859101.

Reinhardt, M., Horváth, Z., Morgan, A., \& Kökönyei, G. (2020). Well-being profiles in adolescence: psychometric properties and latent profile analysis of the mental health continuum model-a methodological study. Health and Quality of Life Outcomes, 18, 1-10.

Ribeiro Santiago, P. H., Nielsen, T., Smithers, L. G., Roberts, R., \& Jamieson, L. (2020). Measuring stress in Australia: validation of the perceived stress scale (PSS-14) in a national sample. Health and Quality of Life Outcomes, 18, 1-16. 
Salin, D., Cowan, R., Adewumi, O., Apospori, E., Bochantin, J., D’Cruz, P., ... \& Išik, I. (2019). Workplace bullying across the globe: A crosscultural comparison. Personnel Review, 48(1), 204-219. https://doi.org/10.1108/PR-03-2017-0092

Skogstad, A., Aasland, M. S., Nielsen, M. B., Hetland, J., Matthiesen, S. B., \& Einarsen, S. (2015). The relative effects of constructive, laissezfaire, and tyrannical leadership on subordinate job satisfaction. Zeitschrift für Psychologie, 222, 221-232. https://doi.org/10.1027/21512604/a000189.

Tepper, B. J., Moss, S. E., Lockhart, D. E., \& Carr, J. C. (2007). Abusive supervision, upward maintenance communication, and subordinates' psychological distress. Academy of Management Journal, 50(5), 1169-1180.

Veliu, L., Manxhari, M., Demiri, V., \& Jahaj, L. (2017). The influence of leadership styles on employee's performance. Management (16487974), 31(2).

Schyns, B., \& Schilling, J. (2013). How bad are the effects of bad leaders? A meta-analysis of destructive leadership and its outcomes. The Leadership Quarterly, 24(1), 138-158.

Van Beveren, P., Dimas, I. D., Lourenço, P. R., \& Rebelo, T. (2017). Psychometric properties of the Portuguese version of the Global Transformational Leadership (GTL) scale. Revista de Psicología del Trabajo y de las Organizaciones, 33(2), $109-114$.

Yukl, G. (2006). Leadership in organizations (6 $6^{\text {th }}$ ed.). Upper Saddle River, NJ: Pearson-Prentice Hall. 